\title{
Macroeconomic Determinants of Cyclical Variations in Value, Size and Momentum premiums in the UK
}

\author{
Golam Sarwar ${ }^{\mathrm{a}}$, \\ Cesario Mateus $^{\mathrm{a}}$, \\ Natasa Todorovic ${ }^{\mathrm{b} *}$, \\ ${ }^{a}$ Univeristy of Greenwich, London, UK \\ ${ }^{b}$ The Centre for Asset Management Research, \\ Cass Business School, City University, London, UK
}

This version: March 2015

\begin{abstract}
The paper examines the asymmetries in size, value and momentum premiums over the economic cycles in the UK and their macroeconomic determinants. Using Markov switching approach we find clear evidence of cyclical variations of the three premiums, most noticeably variations in size premium. We associate Markov switching regime 1 with economic upturn and regime 2 with economic downturn. The macroeconomic indicators prompting such cyclicality the most are growth in industrial production, term structure, credit spread and money supply. Using forecast returns from our model and a trading strategy that alternates between size/style/momentum portfolios and risk-free rate, we show that exploiting cyclicality in premiums proves particularly profitable for portfolios featuring small cap stocks in recessions.
\end{abstract}

JEL classification: G11, E32

Key words: Size, Value and Momentum premiums, Markov Switching, Macroeconomic determinants, Trading strategy

*Corresponding author. Tel.: +44 207040 0120. E-mail addresses: g.sarwar@greenwich.ac.uk (Sarwar), c.mateus@greenwich.ac.uk (Mateus),n.todorovic@city.ac.uk (Todorovic). 


\section{Introduction}

Since Fama-French (1993) and Carhart (1997) related a small cap premium (small-minus-big company returns (SMB)), value premium (high book to market minus low book to market ratio stock returns (HML)) and momentum premium (winner minus loser stock returns (UMD)) to excess returns, a vast body of literature that analyses determinants of those premiums has emerged. While, for instance, DeBondt, Werner, \& Thaler (1985) and Daniel, Hirshleifer, \& Subrahmanyam (1998) argue that the value premium arises due to the overreaction of investors, a number of academic studies points that the value and size premium are proxies for some non-diversifiable risks not captured by the standard CAPM model, such as risks resulting from variations in macroeconomic factors (see Kelly, 2003; Liew \& Vassalou, 2000; Petkova, 2006; Vassalou, 2003; Zhang, Hopkins, Satchell, \& Schwob, 2009; Black and McMillan, 2005; Gulen Xing, \& Zhang, 2008, Kim et al., 2012 and Perez-Quiros \& Timmermann, 2000).

The literature on variety of macroeconomic sources that can cause asymmetries in expected returns of value, small cap and winner portfolios over different phases of business cycle focuses predominantly on the US market. It shows evidence that value portfolio returns respond more to the changes of interest rates and money supply over the recessionary period than expansionary period, supporting the asymmetric behaviour of returns over economic phases (Black and McMillan, 2005). Three distinct sources, namely, costly reversibility, operating leverage and financial leverage have been identified as the sources of relative inflexibility of value firms in mitigating recessionary shocks. Hence these firms are riskier in recessions leading to higher expected value premiums. First, costly reversibility implies the higher cost of firms' to scrap down the scale of productive assets than to expand. Value firms want to disinvest more in economic downturn because their assets are less profitable than those of growth firms; such disinvesting is less important for growth firms (Gulen et al., 2008). Since disinvesting is restricted by costly reversibility, the fundamentals of value firms are affected more severely than the fundamentals of growth firms in economic downturn when the credit market conditions are bad. In similar spirit, Gala (2005) argues that investment irreversibility plays a vital role in explaining the size effects in stock returns and their relation to risk and firms' fundamentals. Second, when the demand of the product of a firm decreases, the stock price of corresponding firm also decreases. This stock fall is in-line with fall in book values and revenues falls relative to average values of the corresponding 
firm. However, the stock prices and revenues of value firms fall more relative to book values and average level, respectively, the value firms ought to have higher operating leverage than growth firms. Moreover, fixed costs of firms do not decrease proportionally with revenues in economic downturn; and hence the earnings (revenue minus fixed and variable costs) will decrease more than proportionally relative to revenues. This operating leverage mechanism will have adverse effect on value firm by the negative aggregate shocks during economic downturn as suggested by Gulen et al. (2008). Third, Livdan, Sapriza, \& Zhang (2009) find that value firms are characterized with higher financial leverage and investors require higher expected returns to hold higher levered stocks during economic downturn when the value firms are more exposed to the financial constraints.

Investigation into the small and large size firms reveals their sources of finance are different implying they should be affected differently by credit market constraints. Perez-Quiros \& Timmermann (2000) argue that worsening credit market conditions in the economic downturns have an adverse effect of on the small cap firms. Chan \& Chen (1991) prove that characteristics of a firm rather than its size matter for the size premium. Specifically, they find a large proportion of marginal firms (with lower production efficiency and higher financial leverage) in the small cap portfolio. Since marginal firms have lost market value because of the poor performance, while having higher financial leverage and cash flow problems; their price tends to be more sensitive to the economic states. Similar is confirmed more recently by Kim \& Burnie (2002).

Firms with recent prior positive return (past winners) are likely to have had relatively more positive growth rate shocks in comparison with the firms with recent prior negative return (past losers), ceteris paribus. Johnson (2002) argues that stock price is a convex function of expected growth, meaning that risk increases with growth rates and hence the stock returns supposed to be more sensitive to the changes in expected growth during the higher expected growth regime. In the case of positive risk premium - expected returns increase with growth rates. Hence, past winners (past losers) tend to have higher (lower) growth rate changes in the recent past, as well as higher (lower) subsequent expected returns (Kim, et al., 2012). Maio \& Santa-Clara (2011) identify three different sources of risk that might explain the momentum anomalies: time varying betas, reinvestment risk and a common macroeconomic variable interest rates. 
The focus of the attention in this search for macroeconomic determinants of varying value, size and momentum premiums over business cycles has by and large been on the US market. Using size, value and momentum factors data from Gregory, Tharyan, \& Christidis, (2013) and Markov-switching model methodology, this paper seeks to contribute to the literature by providing the first comprehensive study of the effect of a set of relevant macroeconomic variables on those premiums in the UK market over varying economic regimes. The Markov Switching framework of this study is closely related to Perez-Quiros \& Timmermann (2000) and Gulen et al. (2008), where the former investigate the systematic difference in variation of size premium while the latter focuses on variations in value premium over the business cycles. This study, however, scrutinizes the relative difference in change between size, value and momentum premium over business cycles impacted by the variation in their responsiveness to macroeconomic variables during different economic phases. In addition, to the best of our knowledge, this is the first study that examines how all three equity premiums are impacted by macroeconomic factors during the recent financial crisis in the UK. We also test statistical forecasting accuracy of our model to predict size/style portfolio returns and explore whether cyclical differences in premiums lead to asymmetries in the economic value added to investors in recessions and expansions. To do this we apply a simple trading rule that allows us to switch between a style/size portfolio and UK one month Treasury bill (depending on the sign of portfolio's forecasted return). We then assess the differences in Sharpe ratios of the strategy during recessions, expansions and the full sample period relative to a buy-and-hold benchmark.

We find that there is clear evidence of asymmetry in size, value and momentum premium over the economic cycles in the UK. The most pronounced asymmetry is associated with size premium. We document that credit market conditions have the greatest impact on the level of the three premiums in both markets states in our sample. Our trading rule results confirm the asymmetry of the premiums over economic cycles, particularly the size premium. Portfolios of small capitalisation stocks sorted by book-to-market ratios and momentum generate greater Sharpe ratios than the corresponding buy-and-hold strategy in recessions, while in expansions their economic value added is at best equal to that of the buy-and-hold. This simple trading applications shows that our model is able to successfully differentiate between the two market states and lead to profitable trading in the down-market. 
The remainder of the paper is organised as follows: Section 2 outlines methodological framework and describes the data; Section 3 discusses the findings before concluding in Section 4.

\section{$2 \quad$ Data and Methodology}

\subsection{Style Premiums}

This study uses monthly UK market data from July 1982 to December 2014. The UK SMB, HML and UMD factor data is from Gregory, Tharayan, and Christidis (2013) ${ }^{1}$, which is comparable with the Fama-French's and Carhart's US equivalents. After sorting on market capitalization, Gregory, Tharayan, and Christidis (2013) form two size groups of UK stocks, namely 'S'-small and 'B'-big by using the median market capitalization of the largest 350 companies in the year ' $t$ ' as the size break point. Similarly, three book-to-market groups, named 'H'-High, 'M'-medium and 'L'-Low are formed by using the 30th and 70th percentiles of book-to-market of the largest 350 firms as break points for the book-to-market. Six intersecting portfolios: $\mathrm{SH}$; $\mathrm{SM}$; SL BH; BM; BL are formed (where "SH" is the small size high book-to-market portfolio, "SL" is the small size low book-to-market portfolio, "BL" is the big size low book-to-market portfolio and so on). SMB and HML factor are then calculated as:

$\mathrm{SMB}=(\mathrm{SL}+\mathrm{SM}+\mathrm{SH}) / 3-(\mathrm{BL}+\mathrm{BM}+\mathrm{BH}) / 3$

And,

$\mathrm{HML}=(\mathrm{SH}+\mathrm{BH}) / 2-(\mathrm{SL}+\mathrm{BL}) / 2$

UMD (momentum) factor is constructed using size and prior (2-12 month) returns ${ }^{2}$. The authors create six portfolios, namely SU (small size and high momentum portfolio); SM (small size and medium momentum portfolio); SD (small size and low momentum portfolio); BU (big size and high momentum portfolio); BM (big size and medium momentum portfolio) and BD (big size and low momentum portfolio). The UMD (Up-Minus-Down, i.e. high minus low momentum return) factor is then calculated as:

$\mathrm{UMD}=(\mathrm{SU}+\mathrm{BU}) / 2-(\mathrm{SD}+\mathrm{BD}) / 2$

\footnotetext{
${ }^{1}$ Downloadable from: http://business-school.exeter.ac.uk/research/areas/centres/xfi/research/famafrench/files/

${ }^{2}$ The prior return at the end of month $t$ is the cumulative return from month $t-12$ to month $t-2$. January is excluded from the calculation to adjust for the seasonal anomalies.
} 
Note that the components used to form the SMB, HML and UMD factors factor are equally weighted.

\subsection{Macroeconomic Factors}

A selection of the UK macroeconomic variables in this study, namely Industrial Production Index (used as a proxy for GDP), Inflation, Interest rate, Term spread, Credit spread and Money supply, is commonly used in the literature of the predictability of stock returns. Table 1 lays out the variables used in this paper as potential determinants of the changes is style premia across economic regimes; their expected relationship with the SMB, HML and UMD premium respectively, the literature that identifies those relationships, the source of data for each variable as well as any transformation of variables applied.

\section{- $\quad$ Table 1 around here-}

GDP indicates real economic growth and a positive relationship between GDP and return premium (size, value and momentum) is identified by many (e.g. Chelley-Steeley \& Siganos, 2004; Kelly, 2003; Liew \& Vassalou, 2000; Zhang et al., 2009). Since GDP figures are published only quarterly, to facilitate monthly data analysis we use Industrial production index as a proxy for monthly GDP growth as in Aretz, Bartram, \& Pope, (2010); Black \& McMillan (2002); Griffin, Ji, \& Martin (2003); Liu \& Zhang (2008); Mouselli, Michou, \& Stark (2008).

The relationship between unexpected inflation and size premium is assumed to be negative, because small firms are affected more in the environment of unexpected inflation, (Zhang et al., 2009); whereas, the relationship with value premium is expected to be positive. This is because value firms pay high dividends relative to growth firms, they perform better in higher inflationary periods (Zhang et al., 2009). According to Fisher's theory if the stocks are hedged against inflation one would expect a positive relationship between inflation and stock returns. Hence the intuitive relationship between momentum premium and inflation is positive. We follow Fama and Gibbons (1984) and Zhang et al. (2009) to calculate the unexpected inflation as per Table 1.

Further, the increase in the short term interest rates affects badly value firms and small cap firms due to their high leverage, uncertainty of cash flows and low durations in general. Moreover, rising interest rate reflects the worsening of credit market conditions (Perez- 
Quiros \& Timmermann, 2000) and thus interest rates are likely to be negatively correlated with contemporaneous stock returns (Gulen et al., 2008). The three months Treasury bill is used as a proxy of risk free interest rate.

Term spread can be viewed as an economic activity indicator and it is a proxy for risk premium. In economic upturn the term spread decreases because short term interest rates increase more than long term interest rates. Whereas, during economic downturn short term interest rates decrease and the spread between long and short term interest rates increases. Term spread may therefore affect expected stock return because it affect the company earnings (Lucas, van Dijk, \& Kloek, 2002). The intuitive relationship between term spread and style premium is positive. We define term spread as the difference between the yield on a 10 year UK government bond and a three-month UK Treasury bill.

Credit spread or default spread has long been used in the literature as a proxy of credit market conditions, se for example Chen et al. (1986), Gertler, Hubbard, \& Kashyap (1990); Kashyap, Lamont, \& Stein (1994); Keim \& Stambaugh (1986), Perez-Quiros and Timmermann (2000), Griffin, Ji and Martin (2003), Gulen et al. (2008), etc. It is obtained as the difference in yields between high yield corporate bond and 10-year UK government bond. The intuitive relationship between credit spread with value and momentum premium is positive. However, since small firms tend to be newcomers, poorly collateralized and don't have full access to the external financial markets, they have relatively stronger adverse effects than large firms to the worsening credit market conditions. On average, an increase (decrease) in the credit spread is expected to be associated with lower (higher) returns of SMB. Moreover, asymmetries are expected for the credit spread variables since firms are likely to be more exposed to credit market conditions during recession (Perez-Quiros and Timmermann, 2000) ${ }^{3}$.

Finally, the change in money supply proxies the liquidity changes and monetary policy shocks (Gulen et al., 2008). It also measures the monetary policy shocks that might affect aggregate economic conditions. Intuitively, changes in money supply effects the economic conditions and investment premium as it indicates the credit market conditions. One could

\footnotetext{
${ }^{3}$ Note that the high yield corporate bond data is not available for the UK market a period longer than 11 years. To cover longer span of varying economic regimes, we resort to Moody's US BAA corporate bond index as a proxy for the UK data. The correlation coefficient Thomson Reuter UK Corporate Benchmark BBB (available since April 2002) and Moody's US BAA is 0.871085 over the 11 year period. Although there is a currency risk involved in the proxy variable it can be minimized by hedging.
} 
expect a higher expected return for an increase in money supply. Small firms are found to be strongly positively affected by lower money supply growth in the study of Perez-Quiros \& Timmermann (2000).

\section{$2.3 \quad$ Econometric framework}

We assume that, investors' investment decisions differ across different economic regimes and further, we assume the relationships of style factors (size, value and momentum) with macroeconomic variables also vary. To characterize economic regimes in style investment return, Perez-Quiros and Timmermann (2000), Guidolin and Timmermann (2008), Gulen, Xing and Zhang (2008), Chung, Hung and Yeh (2012) adopt Markov Switching model. The Markov Switching model, pioneered by Hamilton (1989), gained popularity for studying the asymmetries across business cycle regimes, (Layton \& Smith, 2007). This model allows shifts from one regime to another and also gives probabilities of such transitions. It also takes into account certain types of non-stationarity inherent in economic or financial time series data that cannot be captured by classical linear models. These economic and financial time series might obey to different economic regimes characterized by economic events such as financial crisis (Jeanne and Masson, 2000) or abrupt economic policy changes (Hamilton, 1988), which is relevant for our study. From the econometric point of view, the main challenge of estimating Markov Switching model is the un-observability of the prevailing regime (Ammann \& Verhofen, 2006).

The Markov Switching framework of this study closely related to Perez-Quiros \& Timmermann (2000) and Gulen et al. (2008). We model size, value and momentum premium as follows:

$$
\begin{gathered}
r_{t}=\alpha_{i}+\beta_{i 1, s_{t}} I P_{t-1}+\beta_{i 2, s_{t}} I N F_{t-1}+\beta_{i 3, s_{t}} I R_{t-1}+\beta_{i 4, s_{t}} T_{E R M_{t-1}}+ \\
\beta_{i 5, s_{t}} \operatorname{CREDIT}_{t-1}+\beta_{i 6, s_{t}} \Delta M_{t-2}+\varepsilon_{i t} \quad ; i=(1,2,3)^{\prime}
\end{gathered}
$$

Here, $r_{t}=\left(S M B_{t}, H M L_{t}, U M D_{t}\right)^{\prime}$ is the $(3 \times 1)$ vector of three different style portfolio returns, and $\varepsilon_{i t}$ is normally distributed error term with mean 'zero' and variance $\sigma_{i s_{t}}^{2}$, with $S_{t}=\{1,2\}$, namely regime 1 and regime 2. IP is the Industrial Production growth rate, INF is the inflation; IR is a 3-month Treasury bill, used as a proxy of short term interest rate; TERM is the difference between ten year Government bond and 3-month Treasury bill, representing a term spread; CREDIT is the credit spread defined as the difference in yield between high 
yield bond and ten year Government bond; $\Delta M$ is the log change in money supply, used as a proxy for liquidity changes in the economy.

Following the study of Perez-Quiros and Timmermann (2000), Gulen, Xing and Zhang (2008) and Kim et al. (2012), this study uses the lag of one-month for Industrial Production growth, Inflation, Interest Rates, Term Spread and Credit Spread; whereas, money supply growth is lagged by two months to allow the publication delay of this variable. The model is estimated by the Markov Switching model with Time Varying Transition Probabilities which is feasible estimation method with non-normal data ${ }^{4}$.

The transition probabilities for the above model are specified as:

$$
\begin{aligned}
& P_{11}=P\left(s_{t}=1 \mid s_{t-1}=1, z_{t-1}\right)=\Phi\left(\pi_{0}+\pi_{1} C L I_{t-2}\right) \\
& P_{12}=1-P_{11}=P\left(s_{t}=1 \mid s_{t-1}=2, z_{t-1}\right) \\
& P_{22}=P\left(s_{t}=2 \mid s_{t-1}=2, z_{t-1}\right)=\Phi\left(\pi_{0}+\pi_{2} C L I_{t-2}\right) \\
& P_{21}=1-P_{22}=P\left(s_{t}=2 \mid s_{t-1}=1, z_{t-1}\right)
\end{aligned}
$$

Here, $s_{t}$ is the indicator of regimes for each of the style portfolio and $\Phi$ is the cumulative density function of standard normal variable. CLI is the OECD's Composite Leading Indicator. Prior literature shows that the transition probabilities between regimes are time varying and depend on information variables such as economic leading indicator (see for e.g. Filardo, 1994, Perez-Quiros \& Timmermann, 2000, Gulen et al., 2008, Chung et al., 2012). Layton (1998) argues that, such transition probabilities adjusted by information variables or leading indicators provide very close correspondence to the business cycle chronology. To ensure transition probabilities are accurately defined prior studies used logarithmic lag difference of Composite Leading Indicator. The Composite Leading Indicator is designed to anticipate the turning point of economic cycles relative to trend and continue to signal diverging growth patterns across the corresponding economy. The indicator suffers from back-filling bias, as it is published when $60 \%$ of its data is available and revised as more data

\footnotetext{
${ }^{4}$ See, Hamilton (1988), Hamilton (1994), Kim \& Nelson (1999) and Jeanne \& Masson (2000).
} 
is included. There is a 2 month publication lag for input data for this indicator so that the data for month ' $\mathrm{t}$ ' is available in month ' $\mathrm{t}+2$ ' . To avoid back-filling bias, we apply CLI indicator with lag 2 in this study (as in Perez-Quiros \& Timmermann, 2000 and Gulen et al., 2008).

\subsection{Identification of the States}

Figures 1, 2 and 3 provide an indication of the relation between the Markov switching states and economic regimes. All three figures display the regime probabilities of being in low volatile regime (regime 1) and high volatile regime (regime 2) for size, value and momentum premium respectively at time $\mathrm{t}$ with the conditional information at time $\mathrm{t}-1$. Here, $\mathrm{P}(\mathrm{S}(\mathrm{t})=1)$ and $\mathrm{P}(\mathrm{S}(\mathrm{t})=2)$ are the probability of being in regime 1 and regime 2 respectively. The shaded area is the OECD based Recession Indicators for the United Kingdom taken from Federal Reserve Bank of St. Louis. It can be observed that the predicted probabilities of being in the high volatile (low output) regime coincide with the recessionary period. Figure 1 illustrates that the smoothed regime probabilities display clear time variation of small cap premium across the states of the economy and the probabilities of being in regime 2 is quite high during the recession. Figure 3 also displays the strong time variation of momentum premium across the economic states but the probabilities of being in regime 2 is lower during the economic downturn. This might imply the procyclical behaviour of momentum premium. In contrast, there is no strong time variation across economic states for the value premium in Figure 2. Most variation is observed at the start of 2001/02 around the dot com bubble burst. During that time high probability of value premium being in regime 2 (downturn) is observed. These results further support that the regime 1 is the state of economic upturn and regime 2 is state of economic downturn.

Moreover, we find that that the regime 2 is associated with the high conditional volatility, measured by conditional standard deviation reported in Table 3 for the size, value and momentum premium. These findings are align with those of Schwert (1990), Hamilton and Lin (1996), Gulen et al. (2008), Perez-Quiros \& Timmermann (2000) and Kim et al. (2012). Given this, it can be inferred that the regime 1 corresponds to economic upturn and regime 2 to the economic downturn, which are characterised by low and high volatilities respectively.

- $\quad$ Figure 1 around here -

- Figure 2 around here -

${ }^{5}$ http://www.oecd.org/std/compositeleadingindicatorsclifrequentlyaskedquestionsfaqs.htm 
- $\quad$ Figure 3 around here -

\section{$3 \quad$ Empirical findings}

\subsection{Descriptive Statistics}

Table 2 presents the descriptive statistics (mean, standard deviation, skewness and kurtosis) of the UK size, value and momentum premium in the overall sample period (Panel A) and in economic downturns and upturns ${ }^{6}$ separately (Panel B). The mean returns of size, value and momentum premium in the overall sample period reported in Panel A are $0.129 \%, 0.339 \%$ and $0.766 \%$ with the standard deviation of $0.031,0.032$ and 0.041 respectively.

\section{- $\quad$ Table 2 around here -}

Panel B shows the domination of momentum premium with the mean return (and standard deviation) being highest in both regimes. Panel B documents that while the fall in value and momentum premiums in recessions is very marginal, the size premium exhibits a notable change. It shifts from positive $(0.36 \%)$ in expansions to negative $(-0.07 \%)$ in recessions, which might indicate the poor performance of small firms during the tight credit market conditions. Decrease in size premium in the downmarket state is also documented by Kim \& Burnie (2002). Further, in the overall sample period (Panel A), all but the SMB premium are significantly negatively skewed with kurtosis higher than 3 in all the cases, implying nonnormal distribution. Similar characteristics are also observed during the two economic cycles.

\subsection{Markov Switching Model Results}

Table 3 reports the parameter estimation of the equation (1) by the Markov switching model. The constant term $\left(\alpha_{1}\right)$ in regime 2 is lower than those of regime 1 universally for all the style premiums. This indicates lower expected value of the SMB, HML and UMD after adjusting for the macroeconomic risk factors in the regime 2 then in regime 1. Except for the size and momentum premium in regime 1 , all of the constant terms are significant across the regimes. The highest constant is the one associated with the momentum premium in both regimes. Furthermore, while all three constants decrease when we move from regime 1 to

\footnotetext{
${ }^{6}$ As defined by OECD’s Composite Leading Indicator (CLI) described in section 2.3 of the paper
} 
regime 2, the greatest change in the magnitude of the constant is associated with value premium (0.6019), albeit its sign remains negative. Therefore, we consider the most notable change is in the size premium, as it is the only one that changes from positive in expansion to negative in recession, which is consistent with our findings from Table 2. The constants in Table 3 therefore imply that the investors would benefit from holding big capitalization firms with good opportunities of growth in the recessions, but that the premium on holding winners will not be very high. This is in line with Arshanapalli et al., 2004 and Fama and French, 1993 who document that firms with small capitalization, high book-to-market ratios and past winners are more likely to be distressed and vulnerable during bad economic conditions and investors will be better off avoiding them.

The magnitudes (in absolute terms) of most of the coefficients of macroeconomic variables are higher during economic downturn than economic upturn suggesting that, investors require greater compensation for higher macroeconomic risk (Black and McMillan, 2005). This is most evident for the value premium, where all the coefficients are higher during economic downturn, hinting that investors require additional compensation for holding the extreme book-to-market portfolio. The magnitude of responsiveness of the momentum premium to changes in regimes is comparatively lower.

\section{- $\quad$ Table 3 around here -}

Table 3 also reveals the positive relationship between the growth in industrial production and all the premiums in regime 1 . When the economy is doing well a further increase in the growth of industrial production signals increase in small cap, value and premium on winner stocks, as the literature (see Table 1) suggests. In contrast, in the recessions, growth in industrial production decreases premium of small cap stocks. The reason for this may be the fact that small cap companies are mainly in industries that are cyclical in nature (industrials, technology, consumer discretionary) and heavily affected by recessions, so even if the industrial production grows in the recession it does not improve returns of small caps until the recession is over. We also find that change in industrial production growth has no impact on momentum premium and a positive impact on value premium in recessions.

The coefficients of inflation for size premium are 0.278 and -0.002 during regime 1 and regime 2 respectively. The positive and significant relationship in economic upturn implies that small capitalization stocks benefit from inflation, as the small firms find it relatively 
easier to pass along price increases in inflationary times, an argument provided by Anderson (1997). The negative relationship, although insignificant, between size premium and inflation during regime 2 confirms the views of Chan \& Chen (1991), Kelly (2003) and Zhang et al (2009) that small firms are affected more in the environment of unexpected inflation during adverse economic conditions and are less likely to survive adverse economic states. Since value firms pay higher dividends than growth firms, they perform better when inflation increases, as suggested by Zhang et al (2009). We confirm this positive relationship between value premium and unexpected inflation in both economic states (it is highly statistically significant in regime 2). Finally, momentum premium and inflation exhibit positive and significant relationship in economic upturn suggesting that past winners are at an advantage in periods of increasing inflation. The relationship is found to be insignificant during economic downturn.

According to credit channel theory of monetary policy (Bernanke and Gertler, 1995) monetary tightening increases the financial costs and restricts the access to external financing. This monetary tightening has stronger effect to the firms in poorer financial positions. Our findings are in line with this theory, suggesting that since small firms tend to be low duration firms with high leverage and cash flow problem, higher interest rates will restrict their access to external financing. This relationship is positive in economic downturn, albeit insignificant. Further, we find support for a positive relationship between value premium and interest rates over both regimes. This is consistent with Black and McMillan (2005), indicating that value investors seek higher returns to compensate increased returns on competing assets. Finally, the increase in interest rates by $1 \%$ decreases momentum premium by $0.14 \%$ in regime 2 , which is significant at $10 \%$ level. Hence, past winners are more adversely affected by the changes in short term interest rates in economic downturns than past losers. Although similar relationship is found in regime 1, it is insignificant.

The relationship between the term structure and size and value premium respectively exhibits asymmetries in our findings over economic regimes. Aretz, Bartram \& Pope (2010) argue that shocks to term structure will have greater effect on larger firms than on the smaller ones and hence a positive relationship is expected between term spread and size premium and our results confirm this view in economic downturn. Further, similar to Gregory, Harris, \& Michou (2003), we find that during expansion a steepening in the yield curve has greater positive effect on value premium. However, this effect is found to be negative during 
economic downturn where the spread is larger. Moreover, the negative relationship between term spread and momentum premium indicates that the past losers benefit from the steepening of yield curve both in economic expansion and recession.

An increase in credit spread commonly interpreted as a sign of worsening credit market conditions. One would expect positive relationship between credit spread and style premiums on average and we find evidence that corroborates this in both regimes. We document a positive coefficient of credit spread with size and value premiums during both economic states. This finding coincide with the findings of Fama and French (1988); Fama and French (1989). This might indicate that small and value firms require greater compensation of taking higher risk when the credit spread is higher. However, during expansion the coefficient of credit spread is negative for momentum premium, indicating that past losers enjoy higher return than past winners during economic upturn. Higher magnitudes of credit spread during recession for size and value premiums indicate that firms that exposed to tightening credit market conditions respond more to increased credit risk during bad economic conditions.

Money supply growth appears to show asymmetries with value premiums. Positive coefficients of money supply growth during expansion indicate that value firms take the advantage of higher money supply during expansion. However, this relationship is negative during economic recession. One possible explanation can be value firms are exposed more to the economic downturn and keep safe position despite of higher risk premium. It is also possible that growth firms take the advantage of higher money supply despite of the higher risk in economic downturn. A positive relationship with size and momentum premiums is found during both economic cycles, indicating that both the small firms and past winners take the advantage of money supply growth in both economic conditions.

Overall, our results clearly show the evidence of cyclical asymmetry in size, value and momentum premium. The greatest cyclicality is documented with size and value premiums. Size premium changes sign from being positive in expansion to negative in recession while momentum exhibits the greatest magnitude change. Macroeconomic variables that proxy credit market conditions (term spread and credit spread), industrial production growth and money supply are found to impact the three premiums the most in both high and low volatile market states. 


\subsection{Model Diagnostics}

Economic evidence of asymmetries in stock return is well documented in the literature (see for instance Perez-Quiros \& Timmermann, 2000). To test for asymmetries in our sample and significance of our Markov switching model, we start by employing a Wald test to assess if the coefficients of six conditioning variables (industrial production growth, inflation, interest rates, term spread, credit spread and money supply growth) are identical across regimes for the size, value and momentum premiums, applying the following hypothesis:

For size premium: $H_{01}: \beta_{S M B, j,\left(s_{t}=1\right)}=\beta_{S M B, j,\left(s_{t}=2\right)} ; j=1,2,3,4,5,6$

For value premium: $H_{02}: \beta_{H M L, j,\left(s_{t}=1\right)}=\beta_{H M L, j,\left(s_{t}=2\right)} ; j=1,2,3,4,5,6$

For momentum premium: $H_{03}: \beta_{U M D, j,\left(s_{t}=1\right)}=\beta_{U M D, j,\left(s_{t}=2\right)} ; j=1,2,3,4,5,6$

Table 4 reports that Wald test values of chi-squared distribution with 6 degrees of freedom and the p-values. The significant Chi-Square statistics reject the null hypothesis in favour of regime dependency for all the size, value and momentum premiums. These results identify that the switching model is statistically significant, implying the differential response of style premiums to aggregate economic conditions in the economic downturn and economic upturn. Our results fare well with Perez-Quiros \& Timmermann (2000), Gulen et al. (2008) and Kim et al. (2012).

\section{- $\quad$ Table 4 around here -}

To identify the significance of regressors in the model, the likelihood ratio test for redundant variables is performed. Likelihood ratio rest is being performed under the null hypothesis $\beta_{i j}=0, i=S M B, H M L, U M D ; j=1,2,3,4,5,6$; to identify the significance of each regressor, namely industrial production growth, inflation, interest rates, term spread, credit spread and money supply growth. Table 5 reports the likelihood ratio test of redundant variables for the estimated Time Varying Markov Switching model.

\section{- $\quad$ Table 5 around here -}

With the exception of industrial production growth and money supply in determining the momentum premium, the likelihood ratio test is significant for all of the regressors in size, 
value and momentum premiums. These results corroborate the significant impact our chosen macroeconomic variables have on the three premiums.

\subsection{Regimes robustness check}

The robustness of the model in this study is examined by using different information variable for determining Markov switching model regimes. Parameters of Markov Switching Model are estimated by using industrial production index with lag 1 as an alternative information variable in modelling transitions probabilities instead of composite leading indicator lagged by two periods. If the $\mathrm{IP}_{\mathrm{t}-1}>0$ it is considered as expansionary period and if $\mathrm{IP}_{\mathrm{t}-1}<0$ recessionary. The results in table 6 indicate that our model is robust to the variable used to define the stages of economic cycle. In fact, the alternative measure is more in-line with theoretical and empirical predictions, such as ones documented in Table 1. Credit market variables still remain significant in both regimes for all the premiums.

- $\quad$ Table 6 around here -

While we have shown which variables explain better the value, size and momentum premiums in various regimes, the model's accuracy in predicting actual size/style portfolio returns and usefulness in generating profits for investors in different regimes remains to be tested.

\section{Forecasting accuracy and economic value of the model}

\subsection{Forecasting accuracy of the model}

We probe the practical application of our model from equation (1) by measuring how accurately it can predict returns of eight size/style portfolios available from Gregory, Tharayan, and Christidis (2013) database, namely: small cap-value, small cap-growth, large cap-value, large cap-growth, small cap with-negative momentum, small cap with-positive momentum, large cap with-negative momentum and large cap with-positive momentum. Our data sample is split into 306 in-sample months and 78 out-of-sample (trading) months.

Standard measures to assess forecasting accuracy are applied such as root mean squared error (RMSE), mean absolute error (MAE) and Theil's inequality coefficient (U). The RMSE, MAE and Theil's inequality coefficient is defined as: 


$$
\begin{aligned}
R M S E & =\sqrt{\frac{1}{N} \sum_{t=1}^{N} e_{t+l, t}^{2}}=\sqrt{\frac{1}{N} \sum_{t=1}^{N}\left(\hat{r}_{t+l}-r_{t+l}\right)^{2}} \\
M A E & =\frac{1}{N} \sum_{t=1}^{N}\left|e_{t+l, t}\right|=\frac{1}{N} \sum_{t=1}^{N}\left|\left(\hat{r}_{t+l}-r_{t+l}\right)\right| \\
\boldsymbol{U} & =\frac{\sqrt{\frac{\mathbf{1}}{\boldsymbol{n}} \sum_{n=1}^{n}\left(\hat{r}_{t+l}-r_{t+l}\right)^{2}}}{\sqrt{\frac{\mathbf{1}}{\boldsymbol{n}} \sum_{n=1}^{n}\left(r_{t+l}\right)^{2}}+\sqrt{\frac{\mathbf{1}}{\boldsymbol{n}} \sum_{n=1}^{n}\left(\hat{r}_{t+l}\right)^{2}}}
\end{aligned}
$$

Here, $\hat{r}_{t+1}$ and $r_{t+1}$ are the observed and predicted value respectively.

Table 7 lays out the statistical forecast evaluation results. Lower RMSE, MAE and Theil's inequality values for small firm portfolios (regardless of their sub-classification into high/low book-to-market or positive/negative momentum stocks) by and large confirms the better forecasting accuracy over large firm portfolios.

\section{- $\quad$ Table 7 around here -}

Compared to the book-to-market sorted portfolios, variance proportions from Theil's inequality coefficients of all the momentum portfolios are larger, suggesting that the actual series has fluctuated considerably whereas the forecast has not, i.e. observed returns have higher variance than predicted returns.

Broadly speaking, the results from Table 7 imply that our model is more effective when forecasting returns of portfolios with small cap features and less effective when forecasting those with larger size and with (particularly negative) momentum features. We will therefore test whether our forecasting model leads to a trading strategy with superior risk-adjusted returns when it comes to small cap style portfolios, as suggested by the statistical loss functions.

\subsection{Economic Profitability of the model}

To assess the economic profitability of our model, we use similar asset allocation approach to that given in Perez-Quiros and Timmermann (2000). We start by applying our model to each of the eight size/style portfolio returns from July 1982 to December 2007 to forecast their return for January 2008. If the forecasted return for any of the eight portfolios produced by the model is positive, we invest in that portfolio in January 2008. In the case of negative 
forecast returns, the funds are invested in the proxy for the risk-free asset - UK One Month Treasury Bill. The procedure is then repeated recursively out-of sample over 78 trading months, until June 2014. Our investment strategy is therefore a switching strategy based on alternating between the given size/style portfolio and the T-bill, depending on the sign of the forecast. There are 52 recession months and 26 expansion months in our trading period.

We compare each portfolio switching strategy to the corresponding buy-and-hold benchmark. Buy-and-hold is defined as the investment in the relevant size/style sorted portfolio over the entire 78-month trading period. The risk-adjusted profitability of the switching strategy for each portfolio vs. its buy-and-hold benchmark is measured by the Sharpe ratios. To assess the feasibility of our allocation strategy, we calculate the break-even level of transaction costs per switch for each portfolio. Those are maximum costs per trade that will equalise the Sharpe ratio of the switching strategy to that of the buy-and hold benchmark. The higher the breakeven transaction costs are, the more feasible our strategy is.

Table 8 reports annualised mean return, standard deviation, Sharpe ratio, the number of switches over the trading period and break-even transaction costs per switch for each of the eight switching portfolios. Comparative figures (where applicable) are reported for the buy and hold portfolios. Panel A (Panel B) lays out results for four strategies involving small cap (large cap) portfolio groups: with low book-to-market ratio, with high book-to-market ratio, with down momentum and with up momentum.

Table 8 shows a startling difference in both profitability and feasibility of switching strategies involving small cap (Panel A) and large cap (Panel B) stocks. Given the Sharpe ratios in Panel A, all four small cap switching portfolio categories outperform their buy-and-hold benchmarks in the full out-of-sample period January 2008-December 2014. The average Sharpe ratio of switching portfolios in the full sample in Panel A is 0.65, compared to that of 0.55 of the relevant benchmarks. Breakeven transaction costs are well above at least 100 basis points per switch for all but small cap with up momentum switching portfolio (18.55bps), showing that our small size/style switching strategy is both profitable and feasible. In contrast, Panel B documents that while switching strategies of portfolio of large firms sorted on momentum are not underperforming the buy-and-hold in any instance, their outperformance is not that notable. Large cap portfolio with down momentum generates only marginally higher Sharpe ratio (0.16) than their benchmark (0.15) in the full sample and a less negative Sharpe ratio in recessions. Alternating between large cap firms sorted on book 
to market and the risk free rate does not lead to above-benchmark profitability in any instance.

- Table 8 around here -

The key findings in Table 8 regarding differences in premiums across economic regimes can be interpreted as absolute (level changes) and relative (compared to buy and hold). In absolute terms, premiums per unit of risk (Sharpe ratios) on all portfolios decrease when we move from expansion to recession state. This is coherent with our Markov switching model results which show a drop in size, value and momentum premiums in recession. In our trading period, the drop in Sharpe ratios is highly influenced by the strong negative returns of all portfolios during the period of global financial crisis 2007-2010. Tightening of credit market conditions, which we found to have the strongest impact in determining the size of the three premiums, is a likely cause of this drop.

In relative terms, our findings are in line with those in Perez-Quiros and Timmermann (2000). Our trading strategies show better overall performance relative to buy-and-hold in recession as opposed to expansion. This finding is more pronounced among switching strategies with small cap portfolios (Panel A) than large cap portfolios (Panel B). Specifically, the average Sharpe ratio across four small size switching portfolios is by 0.12 higher than that of the buy-and-hold strategies in recessions. In expansions, it is lower by 0.02 on the average. Their outperformance in recession is distinct at a feasible level of breakeven transaction costs per trade, even for smaller investors. This finding is of particular importance to practitioners, as it proves that our model can successfully differentiate between economic states and that significance of our forecasts has both statistical and economic value.

\section{Summary and conclusions}

This paper sheds light on asymmetries in the UK size, value and momentum premium and identifies the main drivers of these premiums in varying market conditions. We focus on UK SMB, HML and UMD factors defined by Gregory, Tharayan, and Christidis (2013) in the period January 1982 to December 2014. Employing Markov switching methodology, we find evidence in strong support of asymmetry in premiums across Markov switching regimes. Our analysis of regimes related to OECD's Composite Leading Indicator prompts us to conclude that Markov switching regime 1, associated with lower conditional volatility coincides by and 
large with economic upturns and vice versa for regime 2. We find that all three premiums vary across regimes but that most asymmetries are observed in the size premium.

Following the US literature, we test whether the growth in industrial production, inflation, interest rates, term structure, credit spread and money supply are valid determinants of those cyclical variations in UK equity return premiums. We corroborate findings from the US markets in that macroeconomic factors are drivers of equity premiums in both economic upturn and downturn. The strongest impact on size, value and momentum premium have variables that proxy credit market conditions, namely interest rates, term structure and credit spread.

Finally, we examine the statistical accuracy of our model in forecasting size/style portfolio returns and the economic implications of the asymmetries in size, value and momentum premiums on those portfolios. Using eight portfolios sorted on distinctive size/style/momentum combinations we find that simple trading strategy with portfolios featuring small cap characteristics generate better risk-adjusted performance relative to the buy and hold strategy and relative to the comparable large cap portfolios. Further, we find evidence of cyclicality of equity premiums in both absolute and relative terms. In absolute terms, all trading strategies based on eight style/size portfolios exhibit a drop in Sharpe ratios in the recession. In relative terms, all small cap switching strategies and large cap/negative momentum switching display relative outperformance over their buy and hold benchmarks in recessions, but not in expansions. This implies that forecasts based on our model have not only statistical but also strong economic significance for investors.

This paper can be extended following Clare, Sapuric and Todorovic (2010) and Ammann \& Verhofen (2006). Specifically, multi-style rotation strategies, highly applicable particularly among hedge fund investors can be deployed in high and low volatility regimes using forecasting models based on macroeconomic variables suggested in this paper. 


\section{References}

Ammann, M., \& Verhofen, M. (2006). The Effect of Market Regimes on Style Allocation. Financial Markets and Portfolio Management, 20(3), 309-337.

Anderson, R. (1997). A Large versus Small Capitalization Relative Performance Model. In Market Timing Models. Burr Ridge: Irwin Professional Publishing.

Aretz, K., Bartram, S. M., \& Pope, P. F. (2010). Macroeconomic Risks and CharacteristicBased Factor Models. Journal of Banking \& Finance, 34(6), 1383-1399.

Arshanapalli, B. G., D’Ouville, E. L., \& Nelson, W. B. (2004). Are Size, Value, and Momentum Related to Recession Risk? The Journal of Investing, 13(4), 83-87. doi:10.3905/joi.2004.450760

Bernanke, B. S., \& Gertler, M. (1995). Inside the Black Box: The Credit Channel of Monetary Policy Transmission. Journal of Economic Perspectives, 9, 27-48.

Black, A. J., \& McMillan, D. G. (2005). Value and growth stocks and cyclical asymmetries. Journal of Asset Management, 6(2), 104-116. doi:10.1057/palgrave.jam.2240169

Black, A., \& McMillan, D. (2002). The Long Run Value Premium and Economic Activity. Univ. of Aberdeen Acct. \& Fin. Working Paper No. 02-05, 1-22.

Brown, G., Buccellato, T., Chamberlin, G., Chowdhury, S. D., \& Youll, R. (2009). Understanding the Quality of Early Estimates of Gross Domestic Product. Economic and Labour Market Review, 3(12), 43-50.

Carhart, M. (1997). On Persistence of Mutual Fund Performance. Journal of Finance, 52, 5782.

Chan, K. C., \& Chen, N. (1991). Structural and Return Characteristics of Small and Large Firms. The Journal of Finance, 46(4), 1467-1484.

Chelley-steeley, P., \& Siganos, A. (2004). Momentum Profits and Macroeconomic Factors. Applied Economics Letters, 11(7), 433-436. doi:10.1080/1350485042000191719

Chen, N. F., Roll, R., \& Ross, S. A. (1986). Economic Forces and the Stock Market. Journal of Business, 59(3), 383-403.

Chordia, T., \& Shivakumar, L. (2002). Momentum , Business Cycle , and Time-varying. Journal of Finance, 57(2), 985-1019.

Chung, S., Hung, C., \& Yeh, C. (2012). When Does Investor Sentiment Predict Stock Returns? Journal of Empirical Finance, 19(2), 217-240.

Clare, A., Sapuric, S., \& Todorovic, N. (2010). Quantitative or Momentum-Based Multi-style Rotation? UK Experience. Journal of Asset Management, 10, 370-381. 
Daniel, K., Hirshleifer, D., \& Subrahmanyam, A. (1998). Investor Psychology and Security Market Under- and Overreaction. Journal of Finance, 53(6), 1839-1885.

DeBondt, W., \& Thaler, R. (1985). Does the stock market overreact? The Journal of Finance, 40(3), 793-805.

Fama, E. F., \& French, K. R. (1988). Dividend Yields and Expected Stock Returns. Journal of Financial Economics, 22(1), 3-25.

Fama, E. F., \& French, K. R. (1989). Business Conditions and Expected Returns on Stocks and Bonds. Journal of Financial Economics, 25(1), 23-49.

Fama, E., \& French, K. (1993). Common Risk Factors in the Returns on Stocks and Bonds. Journal of Financial Economics, 33(1), 3-56.

Fama, E., \& Gibbons, M. (1984). A Comparison of Inflation Forecasts. Journal of Monetary Economics, 13, 327-348.

Filardo, A. (1994). Business-Cycle Phases and Their Transitional Dynamics. Journal of Business \& Economic Statistics, 12(3), 299-308.

Gala, V. D. (2005). Investment and Returns. Working Paper, University of Chicago.

Gertler, M., Hubbard, R. G., \& Kashyap, A. (1990). Interest Rate Spreads, Credit Constraints, and Investment Fluctuations: an Empirical Investigation. Financial Markets and Financial Crises, 11-32.

Gregory, A., Harris, R., \& Michou, M. (2003). Contrarian Investment and Macroeconomic Risk. Journal of Business Finance and Accounting, 30(1 \& 2), 213-255.

Gregory, A., Tharyan, R., \& Christidis, A. (2013). Constructing and Testing Alternative Versions of the Fama-French and Carhart Models in the UK. Journal of Business Finance \& Accounting, 40(1\&2), 172-214. doi:10.1111/jbfa.12006

Griffin, J., Ji, X., \& Martin, J. (2003). Momentum Investing and Business Cycle Risk: Evidence from Pole to Pole. The Journal of Finance, 58(6), 2515-2547.

Guidolin, M., \& Timmermann, A. (2008). Size and value anomalies under regime shifts. Journal of Financial Econometrics, 6(1), 1-48.

Gulen, H., Xing, Y., \& Zhang, L. (2008). Value versus Growth : Time-Varying Expected Stock Returns. Financial Management, 40(2), 381-407.

Hahn, J., \& Lee, H. (2006). Yield spreads as Alternative Risk Factors for Size and Book-toMarket. Journal of Financial and Quantitative Analysis, 41(2), 245-269.

Hamilton, J. (1989). A New Approach to the Economic Analysis of Nonstationary Time Series and the Business Cycle. Econometrica, 57(2), 357-384. 
Hamilton, J. D. (1988). Rational-Expectations Econometric Analysis of Changes in Regime: an Investigation of the Term Structure of Interest Rates. Journal of Economic Dynamics and Control, 12, 385-423.

Hamilton, J. D. (1994). Time Series Analysis. Princeton: Princeton University Press.

Hamilton, J., \& Lin, G. (1996). Stock Market Volatility and the Business Cycle. Journal of Applied Econometrics, 11, 573-593.

Jeanne, O., \& Masson, P. (2000). Currency Crises, Sunspots, and Markov-Switching Regimes. Journal of International Economics, 50, 327-350.

Johnson, T. C. (2002). Rational Momentum Effects. Journal of Finance, 57(2), 585-608.

Kashyap, A. K., Lamont, O. A., \& Stein, J. C. (1994). Credit conditions and the cyclical behavior of inventories. The Quarterly Journal of Economics, 109(3), 565-592.

Keim, D. B., \& Stambaugh, R. F. (1986). Predicting Returns in the Stock and Bond Markets. Journal of Financial Economics, 17(2), 357-390.

Kelly, P. (2003). Real and Inflationary Macroeconomic Risk in the Fama and French Size and Book-to-Market Portfolio. EFMA 2003 Helsinki Meetings, (October).

Kim, C., \& Nelson, C. R. (1999). State-Space Models with Regime Switching. Cambridge, Massachusetts: MIT Press.

Kim, D., Roh, T., Min, B., \& Byun, S. (2012). Time-Varying Expected Momentum Profits. Working Paper Series, Available at SSRN 2336144.

Kim, M., \& Burnie, D. (2002). The Firm Size Effect and the Economic Cycle. Journal of Financial Research, 40(1), 111-124.

Layton, A. P. (1998). A further test of the influence of leading indicators on the probability of US business cycle phase shifts. International Journal of Forecasting, 14(1), 63-70. doi:10.1016/S0169-2070(97)00051-4

Layton, A. P., \& Smith, D. R. (2007). Business cycle dynamics with duration dependence and leading indicators. Journal of Macroeconomics, 29(4), 855-875. doi:10.1016/j.jmacro.2006.02.003

Liew, J., \& Vassalou, M. (2000). Can book-to-market , size and momentum be risk factors that predict economic growth? Journal of Financial Economics, 57, 221-245.

Liu, L. X., \& Zhang, L. (2008). Momentum Profits, Factor Pricing, and Macroeconomic Risk. Review of Financial Studies, 21(6), 2417-2448. doi:10.1093/rfs/hhn090

Livdan, D., Sapriza, H., \& Zhang, L. (2009). Financially Constrained Stock Returns. Journal of Finance, 64(4), 1827-1862. 
Lucas, A., van Dijk, R., \& Kloek, T. (2002). Stock selection, style rotation, and risk. Journal of Empirical Finance, 9(1), 1-34. doi:10.1016/S0927-5398(01)00043-3

Maio, P., \& Santa-Clara, P. (2011). Value, Momentum, and Short-Term Interest Rates. Working Paper, Nova School of Business and Economics.

Mouselli, S., Michou, M., \& Stark, A. (2008). On the Information Content of the Fama and French Factors in the UK. Manchester Business School, Working Paper, No. 559. Availabe at: http://www.econstor.eu/handle/10419/50698.

OECD. (2013). Composite Leading Indicators (CLIs). Leading Indicators and Tendency Surveys. Retrieved from http://www.oecd.org/std/leadingindicators/compositeleadingindicatorsclisoecdaugust2013.htm

Perez-Quiros, G., \& Timmermann, A. (2000). Firm Size and Cyclical Variations in Stock Returns. The Journal of Finance, 55(3), 1229-1262.

Petkova, R. (2006). Do Fama-French Factors Proxy for Innovations in Predictive Variables? Journal of Finance, 61(2), 581-612.

Schwert, G. W. (1990). Stock Retuns and Real Activity: A Century of Evidence. Journal of Finance, 45, 1237-1257.

Steiner, M. (2009). Predicting Premiums for the Market, Size, Value, and Momentum factors. Financial Markets and Portfolio Management, 23(2), 137-155. doi:10.1007/s11408009-0099-9

Vassalou, M. (2003). News Related to Future GDP Growth as a Risk Factor in Equity Returns. Journal of Financial Economics, 68(1), 47-73.

Zhang, Q. J., Hopkins, P., Satchell, S., \& Schwob, R. (2009). The Link Between Macroeconomic Factors and Style Returns. Journal of Asset Management, 10, 338-355. doi:doi:10.1057/jam.2009.32 
Figure 1: Time Varying Probability of Being in High and Low Volatile Regimes for Size Premium

This figure displays the regime probabilities of being in low volatile regime (regime 1) and high volatile regime (regime 2) for Size premium at time t with the conditional information at time $\mathrm{t}-1$. Here, $\mathrm{P}(\mathrm{S}(\mathrm{t})=1)$ and $\mathrm{P}(\mathrm{S}(\mathrm{t})=2)$ are the probability of being in regime 1 and regime 2 respectively. The shaded area is the OECD based Recession Indicators for the United Kingdom.

\section{Smoothed Regime Probabilities (SMB)}
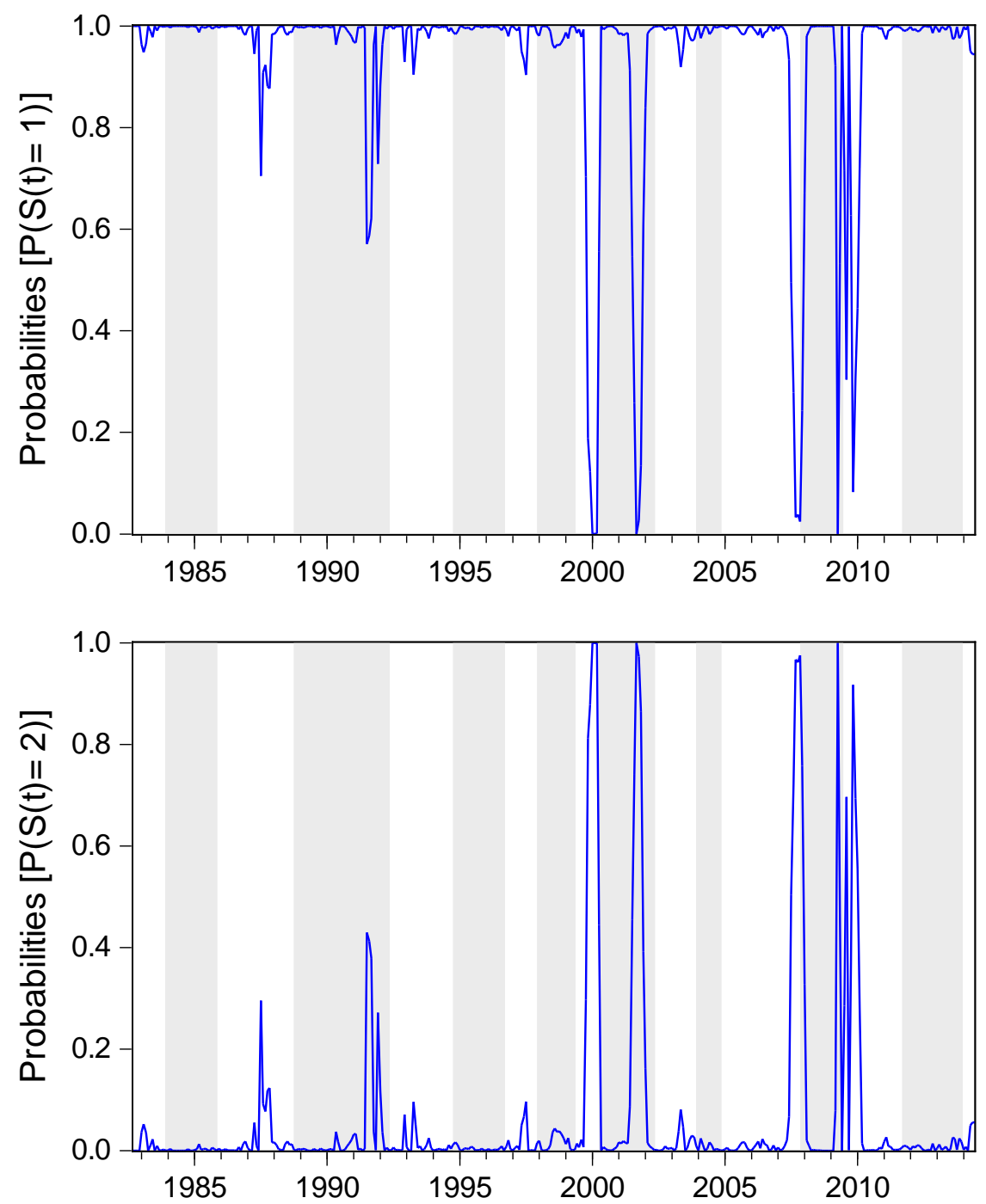
Figure 2: Time Series Probability of Being in High and Low Volatile Regimes for Value Premium

This figure displays the regime probabilities of being in low volatile regime (regime 1) and high volatile regime (regime 2) for Value premium at time $t$ with the conditional information at time $\mathrm{t}-1$. Here, $\mathrm{P}(\mathrm{S}(\mathrm{t})=1)$ and $\mathrm{P}(\mathrm{S}(\mathrm{t})=2)$ are the probability of being in regime 1 and regime 2 respectively. The shaded area is the OECD based Recession Indicators for the United Kingdom.

\section{Smoothed Regime Probabilities (HML)}
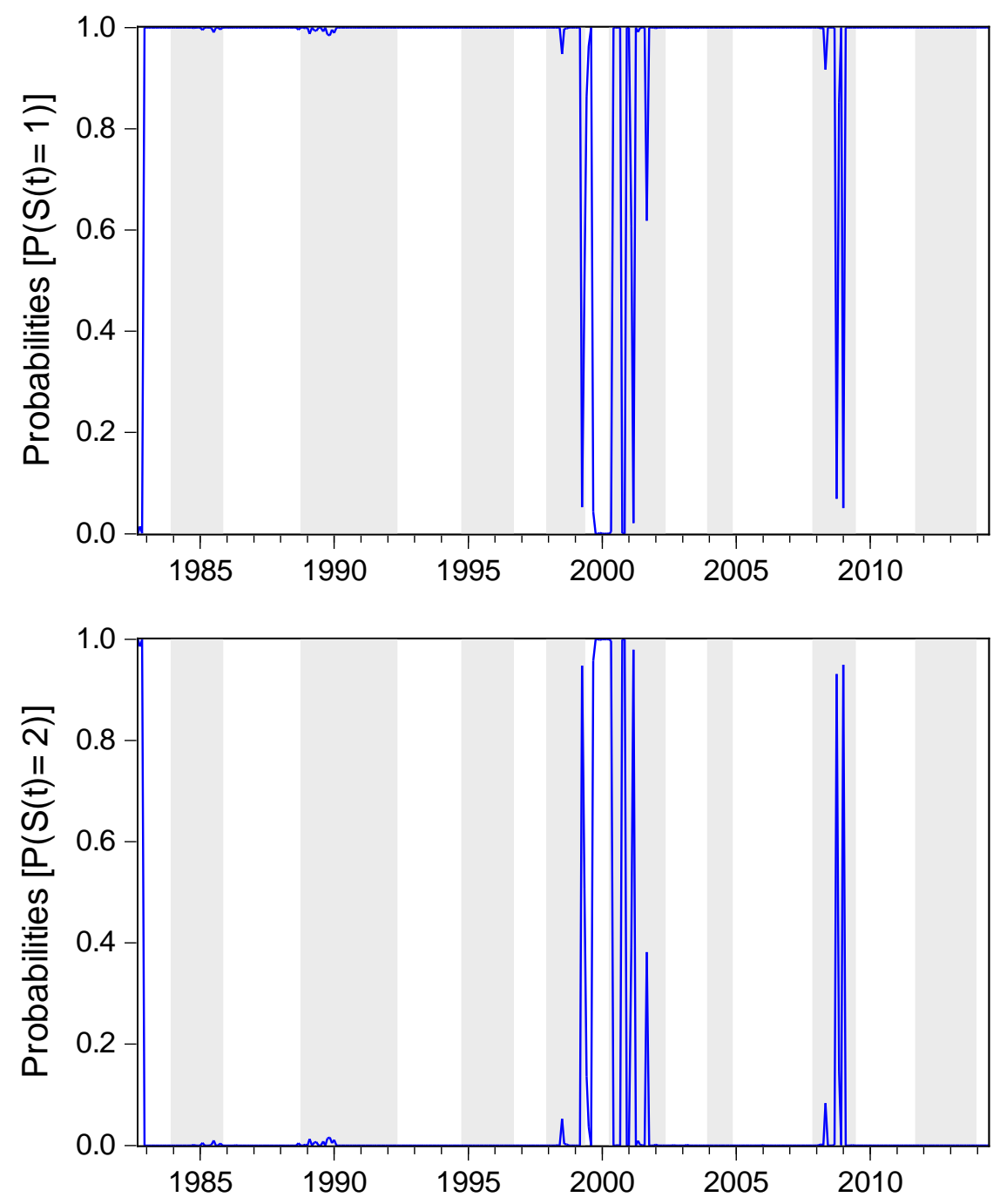
Figure 3: Time Series Probability of being in High and Low Volatile Regimes for Momentum Premium

This figure displays the regime probabilities of being in low volatile regime (regime 1) and high volatile regime (regime 2) for Momentum premium at time t with the conditional information at time $\mathrm{t}-1$. Here, $\mathrm{P}(\mathrm{S}(\mathrm{t})=1)$ and $\mathrm{P}(\mathrm{S}(\mathrm{t})=2)$ are the probability of being in regime 1 and regime 2 respectively. The shaded area is the OECD based Recession Indicators for the United Kingdom.

\section{Smoothed Regime Probabilities (UMD)}
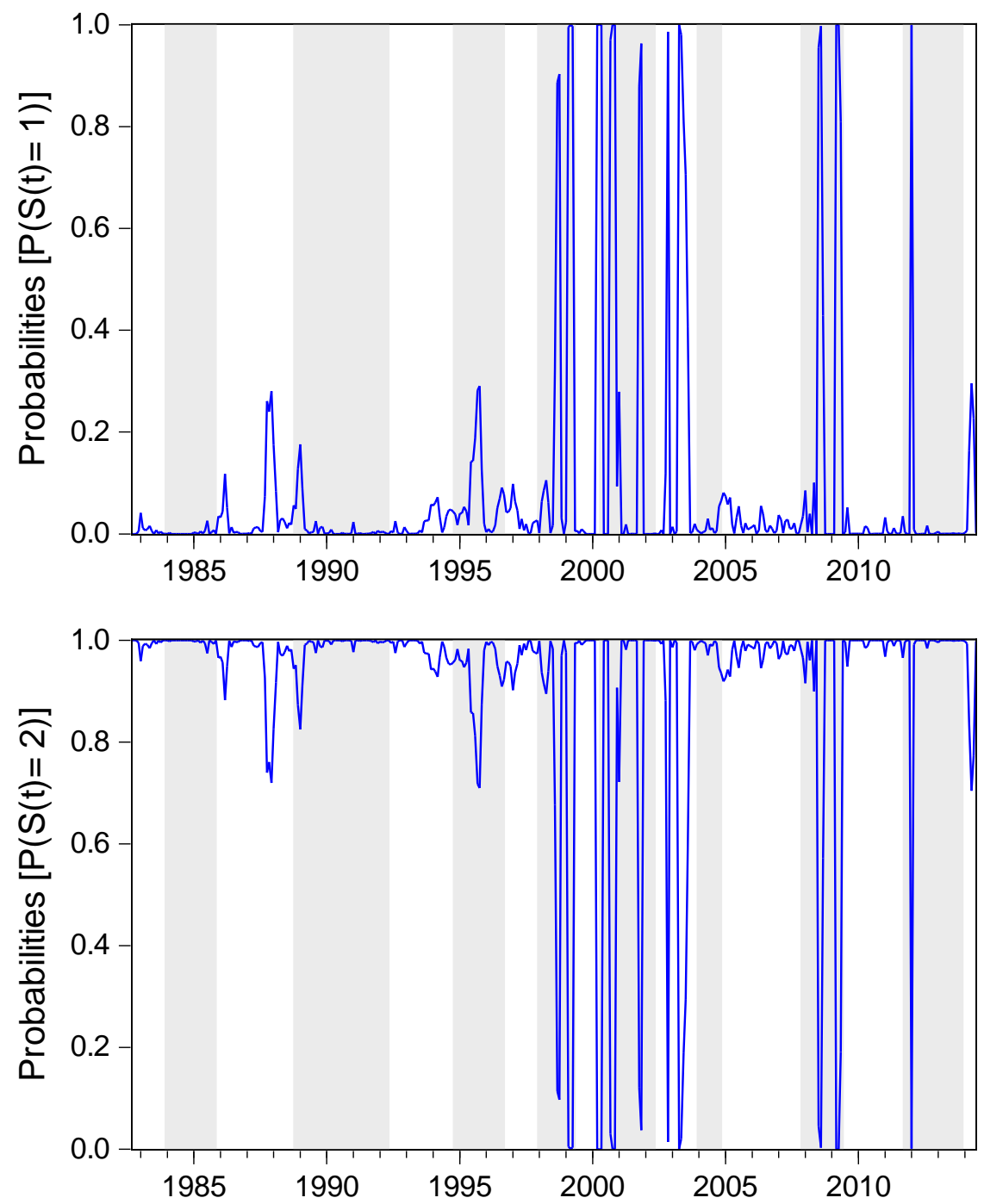


\section{Table 1: Macroeconomic variables}

The table grids all macroeconomic variables used in this study; their expected relationship to SMB, HML and UMD; academic study(ies) that report the relationship and how the variable is transformed for the purpose of this study

\begin{tabular}{|c|c|c|c|c|c|c|}
\hline Variable name & $\begin{array}{l}\text { Relationship } \\
\text { with SMB }\end{array}$ & $\begin{array}{l}\text { Relationship } \\
\text { with HML }\end{array}$ & $\begin{array}{l}\text { Relationship } \\
\text { with UMD }\end{array}$ & Study which reports the relationship & Variable used in our study as: & Data source \\
\hline IP growth & Positive & Positive & Positive & $\begin{array}{l}\text { Aretz, Bartram, \& Pope (2010), Black \& McMillan (2002), Griffin, Ji, \& Martin } \\
\text { (2003), Liu \& Zhang (2008); Mouselli, Michou, \& Stark (2008), etc. }\end{array}$ & IPgrowth $=\ln \left(I_{t}\right)-\ln \left(I P_{t-1}\right)$ & $\begin{array}{l}\text { OECD } \\
(2013, b)\end{array}$ \\
\hline $\begin{array}{l}\text { Unexpected } \\
\text { Inflation (I) }\end{array}$ & Negative & Positive & Negative & Kelly (2003), Kim et al. (2012), Zhang et al. (2009) & $\begin{array}{l}\text { Unexpected } \mathrm{I}_{\mathrm{t}}=\ln \left(\mathrm{CPI}_{\mathrm{t}}\right)-\ln \left(\mathrm{CPI}_{\mathrm{t}-1}\right) \\
\text { Where CPI is consumer price index, } \\
\text { taking } 2005 \text { as base year }\end{array}$ & Datastream \\
\hline Interest rate & Negative & Negative & Negative & $\begin{array}{l}\text { Gulen et al. (2008), Kim et al. (2012), Maio \& Santa-Clara, (2011), Zhang et al. } \\
\text { (2009), etc. }\end{array}$ & 3 months UK Treasury bill & Datastream \\
\hline Term spread & Positive & Positive & Positive & $\begin{array}{l}\text { Aretz, Bartram, \& Pope (2010), Chordia \& Shivakumar (2002), Lucas, van Dijk, } \\
\text { \& Kloek (2002), Hahn \& Lee (2006), Petkova (2006), etc. }\end{array}$ & $\begin{array}{l}\text { Term spread }=10 \text { year UK government } \\
\text { bond yield }-3 \text { months T-bill yield }\end{array}$ & Datastream \\
\hline Credit spread & Negative & Positive & Positive & $\begin{array}{l}\text { Chordia \& Shivakumar (2002), Gulen et al. (2008), Perez-Quiros \& } \\
\text { Timmermann (2000), Hahn \& Lee (2006), Petkova (2006), etc. }\end{array}$ & $\begin{array}{l}\text { Credit spread }=\text { Moody's US BBA yield - } \\
10 \text { year UK government bond yield }\end{array}$ & Datastream \\
\hline $\begin{array}{l}\text { Money supply } \\
\text { (M2) }\end{array}$ & Positive & Positive & Positive & Gulen et al. (2008), Perez-Quiros \& Timmermann (2000), Steiner (2009),etc. & $\mathrm{M} 2=\ln \left(\mathrm{M} 2_{\mathrm{t}}\right)-\ln \left(\mathrm{M} 2_{\mathrm{t}-1}\right)$ & Datastream \\
\hline
\end{tabular}


Table 2: Descriptive Statistics of Style Premiums

This table reports the Mean, Standard Deviation, Skewness and Kurtosis of different style based factor returns.

Panel A reports the values of overall sample period. Whereas, Panel B reports the values over the business cycles. St. Louis fed's recession index is used to define recessions and expansions. The values in the parentheses represent the p-values of Skewness-Kurtosis test for normality.

\begin{tabular}{ccccc}
\hline Panel A & & & & \\
\hline & Mean & Standard Deviation & $\begin{array}{c}\text { Coefficient } \\
\text { of Skewness }\end{array}$ & $\begin{array}{c}\text { Coefficient } \\
\text { of Kurtosis }\end{array}$ \\
\hline SMB & 0.001289 & 0.030979 & $\begin{array}{c}0.1106266 \\
(0.3687)\end{array}$ & $\begin{array}{c}5.229511 \\
(0.0000)^{* * *}\end{array}$ \\
\hline HML & 0.003390 & 0.032235 & $\begin{array}{c}-.5948175 \\
(0.0000)^{* * *}\end{array}$ & $\begin{array}{c}9.605046 \\
(0.0000)^{* * *}\end{array}$ \\
\hline UMD & 0.007663 & 0.041134 & $\begin{array}{c}-1.293105 \\
(0.0000)^{* * *}\end{array}$ & $\begin{array}{c}10.97003 \\
(0.0000)^{* * *}\end{array}$ \\
\hline Panel B & & & & $\begin{array}{c}\text { Coefficient } \\
\text { of Skewness }\end{array}$ \\
\hline \\
\cline { 2 - 6 }
\end{tabular}

$* * *$ Implies the significance at $1 \%$ level of significance, i.e. the hypothesis of normality is rejected.

** Implies the significance at 5\% level of significance, i.e. the hypothesis of normality is rejected.

*Implies the significance at $10 \%$ level of significance, i.e. the hypothesis of normality is rejected. 


\section{Table 3: Parameter estimation of Markov Switching Model}

The estimated two-state Markov switching model is:

$$
\begin{gathered}
r_{t}=\alpha_{1}+\beta_{i 1, s_{t}} I P_{t-1}+\beta_{i 2, s_{t}} I N F_{t-1}+\beta_{i 3, s_{t}} I R_{t-1}+\beta_{i 4, s_{t}} T E R M_{t-1}+\beta_{i 5, s_{t}} C R E D I T_{t-1}+\beta_{i 6, s_{t}} \Delta M_{t-2}+\varepsilon_{i t} ; \\
i=(1,2,3) ; \quad \varepsilon_{i t} \sim N\left(0, \sigma_{i t}^{2}\right), \quad S_{t}=\{1,2\}, \quad r_{t}=\left(S M B_{t}, H M L_{t}, U M D_{t}\right) \\
P_{11}=P\left(s_{t}=1 \mid s_{t-1}=1, z_{t-1}\right)=\Phi\left(\pi_{0}+\pi_{1} C L I_{t-2}\right), P_{12}=1-P_{11} \\
P_{22}=P\left(s_{t}=2 \mid s_{t-1}=2, z_{t-1}\right)=\Phi\left(\pi_{0}+\pi_{2} C L I_{t-2}\right), P_{21}=1-P_{22}
\end{gathered}
$$

Here $r_{i t}$ is the return of size, value and momentum factors. IP is the industrial production growth, INF is the realized

\begin{tabular}{|c|c|c|c|c|}
\hline & & SMB & HML & UMD \\
\hline \multirow{8}{*}{ 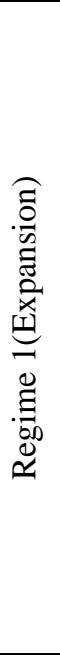 } & $\alpha_{1}$ & $\begin{array}{c}0.002050 \\
(0.7719)\end{array}$ & $\begin{array}{c}-0.016951 \\
(0.0035)^{* * *}\end{array}$ & $\begin{array}{c}0.087443 \\
(0.2779)\end{array}$ \\
\hline & $I P_{t-1}$ & $\begin{array}{c}0.460329 \\
(0.0058)^{* * *}\end{array}$ & $\begin{array}{c}0.140744 \\
(0.2140)\end{array}$ & $\begin{array}{c}2.706269 \\
(0.0000)^{* * *}\end{array}$ \\
\hline & $I N F_{t-1}$ & $\begin{array}{c}0.277594 \\
(0.0506)^{* *}\end{array}$ & $\begin{array}{l}0.088160 \\
(0.4708)\end{array}$ & $\begin{array}{c}2.004497 \\
(0.0066)^{* * *}\end{array}$ \\
\hline & $I R_{t-1}$ & $\begin{array}{c}-0.106737 \\
(0.1723)\end{array}$ & $\begin{array}{c}0.185143 \\
(0.0025)^{* * *}\end{array}$ & $\begin{array}{l}-0.657104 \\
(0.5989)\end{array}$ \\
\hline & $T E R M_{t-1}$ & $\begin{array}{c}-0.067838 \\
(0.6591)\end{array}$ & $\begin{array}{c}0.279666 \\
(0.0311)^{* *}\end{array}$ & $\begin{array}{l}-1.154227 \\
(0.5008)\end{array}$ \\
\hline & $C R E D I T_{t-1}$ & $\begin{array}{l}0.118638 \\
(0.4553)\end{array}$ & $\begin{array}{c}0.398503 \\
(0.0019)^{* * *}\end{array}$ & $\begin{array}{c}-5.820799 \\
(0.0000)^{* * *}\end{array}$ \\
\hline & $\Delta M_{t-2}$ & $\begin{array}{c}0.420119 \\
(0.0200)^{* * *}\end{array}$ & $\begin{array}{l}0.160030 \\
(0.3541)\end{array}$ & $\begin{array}{c}2.560982 \\
(0.0001)^{* * *}\end{array}$ \\
\hline & $\begin{array}{c}\text { Conditional Standard } \\
\text { Deviation }\end{array}$ & 0.048421 & 0.010467 & 0.007827 \\
\hline \multirow{8}{*}{ 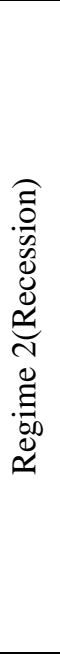 } & $\alpha_{1}$ & $\begin{array}{l}-0.152609 \\
(0.0798)^{*}\end{array}$ & $\begin{array}{c}-0.618901 \\
(0.0000)^{* * *}\end{array}$ & $\begin{array}{c}0.018772 \\
(0.0106)^{* * *}\end{array}$ \\
\hline & $I P_{t-1}$ & $\begin{array}{c}-5.126006 \\
(0.0001)^{* * *}\end{array}$ & $\begin{array}{c}5.267273 \\
(0.0000)^{* * *}\end{array}$ & $\begin{array}{l}-0.005785 \\
(0.9776)\end{array}$ \\
\hline & $I N F_{t-1}$ & $\begin{array}{c}-0.002372 \\
(0.9980)\end{array}$ & $\begin{array}{c}2.257741 \\
(0.0096)^{* * *}\end{array}$ & $\begin{array}{c}0.179861 \\
(0.3472)\end{array}$ \\
\hline & $I R_{t-1}$ & $\begin{array}{l}1.236731 \\
(0.2138)\end{array}$ & $\begin{array}{c}0.993996 \\
(0.3730)\end{array}$ & $\begin{array}{l}-0.137341 \\
(0.1011)^{*}\end{array}$ \\
\hline & $T E R M_{t-1}$ & $\begin{array}{c}1.963689 \\
(0.2511)\end{array}$ & $\begin{array}{c}-16.90658 \\
(0.0000)^{* * *}\end{array}$ & $\begin{array}{c}-0.488870 \\
(0.0068)^{* * *}\end{array}$ \\
\hline & CREDIT $_{t-1}$ & $\begin{array}{c}3.065277 \\
(0.0345) * *\end{array}$ & $\begin{array}{c}19.69946 \\
(0.0000)^{* * *}\end{array}$ & $\begin{array}{c}0.437187 \\
(0.0259)^{* *}\end{array}$ \\
\hline & $\Delta M_{t-2}$ & $\begin{array}{l}2.466714 \\
(0.0794)^{*} \\
\end{array}$ & $\begin{array}{c}-2.447925 \\
(0.0042)^{* * *}\end{array}$ & $\begin{array}{c}0.023014 \\
(0.9241) \\
\end{array}$ \\
\hline & $\begin{array}{c}\text { Conditional Standard } \\
\text { Deviation } \\
\end{array}$ & 0.072306 & 0.135148 & 0.031385 \\
\hline
\end{tabular}
inflation, and IR is the short term interest rate. TERM is the term spread, CREDIT is the credit spread and $\triangle \mathrm{M}$ is the growth of money supply; and CLI is the OECD's Composite Leading Indicator. The values in the parentheses represent the p-values.

*** Implies the significance at $1 \%$ level of significance.

** Implies the significance at 5\% level of significance.

* Implies the significance at $10 \%$ level of significance. 
This table reports the Wald test's outcome for the hypothesis testing of switches in the intercept and switches in the slope.

The test statistics for the Wald test are:

$$
\begin{aligned}
& \text { For, } H_{0}: \alpha_{i 1}=\alpha_{i 2} ; \frac{\left(\widehat{\alpha}_{1}-\widehat{\alpha}_{2}\right)^{2}}{\operatorname{Var}\left(\widehat{\alpha}_{1}\right)+\operatorname{Var}\left(\widehat{\alpha}_{1}\right)-2 \operatorname{cov}\left(\widehat{\alpha}_{1}, \widehat{\alpha}_{2}\right)} \approx \chi^{2}(1) ; i=S M B, H M L, U M D \\
& \text { For } H_{0}: \beta_{j 1}=\beta_{j 2} ; \frac{\left(\widehat{\beta}_{1}-\widehat{\beta}_{2}\right)^{2}}{\operatorname{Var}\left(\widehat{\beta}_{1}\right)+\operatorname{Var}\left(\widehat{\beta}_{1}\right)-2 \operatorname{cov}\left(\widehat{\beta}_{1}, \widehat{\beta}_{2}\right)} \approx \chi^{2}(6) ; J=1,2,3,4,5,6
\end{aligned}
$$

\begin{tabular}{c|c|c|c}
\hline Hypothesis & $\begin{array}{c}\text { SMB } \\
\text { (Chi-Square) }\end{array}$ & $\begin{array}{c}\text { HML } \\
\text { (Chi-Square) }\end{array}$ & $\begin{array}{c}\text { UMD } \\
\text { (Chi-Square) }\end{array}$ \\
\hline $\begin{array}{c}\text { Switches in the Intercept } \\
H_{01}: \alpha_{S M B,\left(s_{t}=1\right)}=\alpha_{S M B,\left(s_{t}=2\right)}\end{array}$ & 3.073713 & 72.09472 & 0.733652 \\
$H_{02}: \alpha_{H M L,\left(s_{t}=1\right)}=\alpha_{H M L,\left(s_{t}=2\right)}$ & $(0.0796)^{*}$ & $(0.0000)^{* * *}$ & \\
$H_{03}: \alpha_{U M D,\left(s_{t}=1\right)}=\alpha_{U M D,\left(s_{t}=2\right)}$ & & & \\
& & & $10.3917)$ \\
Switches in the Slope & & 435.2303 & $(0.0000)^{* * *}$ \\
$H_{01}: \beta_{S M B, j,\left(s_{t}=1\right)}=\beta_{S M B, j,\left(s_{t}=2\right)}$ & & $(0.0000)^{* * *}$ & \\
$H_{02}: \beta_{H M L, j,\left(s_{t}=1\right)}=\beta_{H M L, j,\left(s_{t}=2\right)}$ & $(0.0000)^{* * *}$ & & \\
$H_{03}: \beta_{U M D, j,\left(s_{t}=1\right)}=\beta_{U M D, j,\left(s_{t}=2\right)}$ & & & \\
$j=1,2,3,4,5,6$ & & & \\
\hline
\end{tabular}

*** Implies the significance at $1 \%$ level of significance.

* Implies the significance at $10 \%$ level of significance. 


\section{Table 5: Likelihood Ratio Test for Redundant Variable}

This table reports the likelihood ratio test for the redundant variables to identify the significance of the regressors in the models.

The estimated two-state Markov switching model is:

$$
\begin{gathered}
r_{t}=\alpha_{1}+\beta_{i 1, s_{t}} I P_{t-1}+\beta_{i 2, s_{t}} I N F_{t-1}+\beta_{i 3, s_{t}} I R_{t-1}+\beta_{i 4, s_{t}} T E R M_{t-1}+\beta_{i 5, s_{t}} C_{\text {CREDIT }}+\beta_{t-1}+\beta_{i, s_{t}} \Delta M_{t-2}+\varepsilon_{i t} ; \\
i=(1,2,3) ; \quad \varepsilon_{i t} \sim N\left(0, \sigma_{i t}^{2}\right), \quad S_{t}=\{1,2\}, \quad r_{t}=\left(S M B_{t}, H M L_{t}, U M D_{t}\right) \\
P_{11}=P\left(s_{t}=1 \mid s_{t-1}=1, z_{t-1}\right)=\Phi\left(\pi_{0}+\pi_{1} C L I_{t-2}\right), P_{12}=1-P_{11} \\
P_{22}=P\left(s_{t}=2 \mid s_{t-1}=2, z_{t-1}\right)=\Phi\left(\pi_{0}+\pi_{2} C L I_{t-2}\right), P_{21}=1-P_{22}
\end{gathered}
$$

Here $r_{i t}$ is the return of size, value and momentum factors. IP is the industrial production growth, INF is the realized

\begin{tabular}{|c|c|c|c|}
\hline Likelihood Ratio & SMB & HML & UMD \\
\hline Unrestricted Log Likelihood & 823.9593 & 855.0250 & 749.6090 \\
\hline $\begin{array}{c}\text { Log Likelihood with } \\
\beta_{i 1}=0, \\
i=S M B, H M L, U M D\end{array}$ & $\begin{array}{c}821.2676 \\
(0.0203)^{* *}\end{array}$ & $\begin{array}{c}831.3902 \\
(0.0000)^{* * *}\end{array}$ & $\begin{array}{c}749.5508 \\
(0.733)\end{array}$ \\
\hline $\begin{array}{c}\text { Log Likelihood with } \\
\beta_{i 2}=0, \\
i=S M B, H M L, U M D\end{array}$ & $\begin{array}{c}818.3032 \\
(0.0000)^{* * *}\end{array}$ & $\begin{array}{c}850.0425 \\
(0.0016)^{* * *}\end{array}$ & $\begin{array}{c}743.8299 \\
(0.0007)^{* * *}\end{array}$ \\
\hline $\begin{array}{c}\text { Log Likelihood with } \\
\beta_{i 3}=0, \\
i=S M B, H M L, U M D\end{array}$ & $\begin{array}{c}821.7076 \\
(0.0338)^{* *}\end{array}$ & $\begin{array}{c}846.9503 \\
(0.0000)^{* * *}\end{array}$ & $\begin{array}{c}747.4198 \\
(0.0364)^{* *}\end{array}$ \\
\hline $\begin{array}{c}\text { Log Likelihood with } \\
\beta_{i 4}=0, \\
i=S M B, H M L, U M D\end{array}$ & $\begin{array}{c}817.4385 \\
(0.0000)^{* * *}\end{array}$ & $\begin{array}{c}819.9147 \\
(0.0000)^{* * *}\end{array}$ & $\begin{array}{c}744.0938 \\
(0.0009) * * *\end{array}$ \\
\hline $\begin{array}{c}\text { Log Likelihood with } \\
\beta_{i 5}=0, \\
i=S M B, H M L, U M D\end{array}$ & $\begin{array}{c}818.6331 \\
(0.0000)^{* * *}\end{array}$ & $\begin{array}{c}844.2326 \\
(0.0001)^{* * *}\end{array}$ & $\begin{array}{c}734.6549 \\
(0.0000)^{* * *}\end{array}$ \\
\hline $\begin{array}{c}\text { Log Likelihood with } \\
\beta_{i 6}=0, \\
i=S M B, H M L, U M D\end{array}$ & $\begin{array}{c}818.2258 \\
(0.0000)^{* * *}\end{array}$ & $\begin{array}{c}851.0871 \\
(0.005)^{* * *}\end{array}$ & $\begin{array}{l}749.2509 \\
(0.3974)\end{array}$ \\
\hline
\end{tabular}
inflation, and IR is the short term interest rate. TERM is the term spread, CREDIT is the credit spread and $\triangle \mathrm{M}$ is the growth of money supply; and CLI is the OECD's Composite Leading Indicator. The p-value of likelihood ratio test indicates the probability of the insignificance of corresponding regressor.

*** Implies the significance at $1 \%$ level of significance.

** Implies the significance at 5\% level of significance.

* Implies the significance at $10 \%$ level of significance. 
Table 6: Parameter Estimation of Markov Switching Model: Using IP Index as an

\section{Alternative Information Variable in Modelling Transitions Probabilities}

$$
\begin{gathered}
\text { The estimated two-state Markov switching model is: } \\
r_{t}=\alpha_{1}+\beta_{i 1, s_{t}} I P_{t-1}+\beta_{i 2, s_{t}} I N F_{t-1}+\beta_{i 3, s_{t}} I R_{t-1}+\beta_{i 4, s_{t}} T E R M_{t-1}+\beta_{i 5, s_{t}} C R E D I T_{t-1}+\beta_{i b, s_{t}} \Delta M_{t-2}+\varepsilon_{i t} \\
i=(1,2,3) ; \quad \varepsilon_{i t} \sim N\left(0, \sigma_{i t}^{2}\right), \quad S_{t}=\{1,2\}, \quad r_{t}=\left(S M B_{t}, H M L_{t}, U M D_{t}\right) \\
P_{11}=P\left(s_{t}=1 \mid s_{t-1}=1, z_{t-1}\right)=\Phi\left(\pi_{0}+\pi_{1} I P_{t-1}\right), P_{12}=1-P_{11} \\
P_{22}=P\left(s_{t}=2 \mid s_{t-1}=2, z_{t-1}\right)=\Phi\left(\pi_{0}+\pi_{2} I P_{t-1}\right), P_{21}=1-P_{22}
\end{gathered}
$$

\begin{tabular}{|c|c|c|c|c|}
\hline & & SMB & HML & UMD \\
\hline \multirow{8}{*}{ 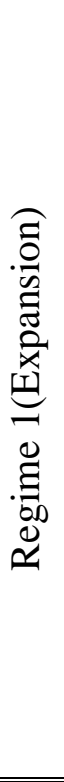 } & $\alpha_{1}$ & $\begin{array}{l}0.000496 \\
(0.9443)\end{array}$ & $\begin{array}{c}-0.015703 \\
(0.0072)^{* * *}\end{array}$ & $\begin{array}{c}0.018888 \\
(0.0099)^{* * *}\end{array}$ \\
\hline & $I P_{t-1}$ & $\begin{array}{c}0.436549 \\
(0.0085) * * *\end{array}$ & $\begin{array}{l}0.177427 \\
(0.1202)\end{array}$ & $\begin{array}{l}0.009767 \\
(0.9616)\end{array}$ \\
\hline & $I N F_{t-1}$ & $\begin{array}{l}0.250148 \\
(0.0855)^{*}\end{array}$ & $\begin{array}{l}0.085308 \\
(0.4824)\end{array}$ & $\begin{array}{l}0.204775 \\
(0.2752)\end{array}$ \\
\hline & $I R_{t-1}$ & $\begin{array}{c}-0.111934 \\
(0.1521)\end{array}$ & $\begin{array}{c}0.183516 \\
(0.0035)^{* * *}\end{array}$ & $\begin{array}{l}-0.140968 \\
(0.0914)^{*}\end{array}$ \\
\hline & $T E R M_{t-1}$ & $\begin{array}{c}-0.065204 \\
(0.6730)\end{array}$ & $\begin{array}{c}0.279805 \\
(0.0338)^{* *}\end{array}$ & $\begin{array}{c}-0.491160 \\
(0.0064)^{* * *}\end{array}$ \\
\hline & $\operatorname{CREDIT}_{t-1}$ & $\begin{array}{l}0.083095 \\
(0.5988)\end{array}$ & $\begin{array}{c}0.329412 \\
(0.0097)^{* * *}\end{array}$ & $\begin{array}{c}0.472901 \\
(0.0176)^{* *}\end{array}$ \\
\hline & $\Delta M_{t-2}$ & $\begin{array}{c}0.660937 \\
(0.0007)^{* * *}\end{array}$ & $\begin{array}{c}0.140285 \\
(0.4186) \\
\end{array}$ & $\begin{array}{c}0.017724 \\
(0.9413) \\
\end{array}$ \\
\hline & $\begin{array}{c}\text { Conditional Standard } \\
\text { Deviation }\end{array}$ & 0.003953 & 0.003765 & 0.005878 \\
\hline \multirow{8}{*}{ 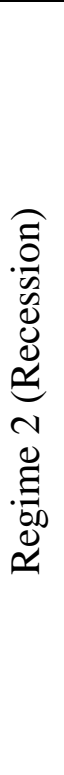 } & $\alpha_{1}$ & $\begin{array}{l}-0.148150 \\
(0.1094)^{*}\end{array}$ & $\begin{array}{c}-0.552269 \\
(0.0000)^{* * *}\end{array}$ & $\begin{array}{c}0.081716 \\
(0.1868)\end{array}$ \\
\hline & $I P_{t-1}$ & $\begin{array}{c}-4.919540 \\
(0.0000) * * *\end{array}$ & $\begin{array}{c}5.149905 \\
(0.0005)^{* * * *}\end{array}$ & $\begin{array}{c}2.810317 \\
(0.0000)^{* * * *}\end{array}$ \\
\hline & $I N F_{t-1}$ & $\begin{array}{l}-2.371646 \\
(0.0299)^{* *}\end{array}$ & $\begin{array}{c}3.682423 \\
(0.0001)^{* * *}\end{array}$ & $\begin{array}{c}1.695842 \\
(0.0083)^{* * *}\end{array}$ \\
\hline & $I R_{t-1}$ & $\begin{array}{l}1.968761 \\
(0.0882)^{*}\end{array}$ & $\begin{array}{c}4.037145 \\
(0.0000)^{* * *}\end{array}$ & $\begin{array}{l}-0.657901 \\
(0.4774)\end{array}$ \\
\hline & $T E R M_{t-1}$ & $\begin{array}{c}5.913632 \\
(0.0019) * * *\end{array}$ & $\begin{array}{c}-19.43269 \\
(0.0000)^{* * *}\end{array}$ & $\begin{array}{l}-0.960671 \\
(0.4660)\end{array}$ \\
\hline & CREDIT $_{t-1}$ & $\begin{array}{l}2.579501 \\
(0.0834)^{*}\end{array}$ & $\begin{array}{c}11.22112 \\
(0.0000)^{* * *}\end{array}$ & $\begin{array}{c}-5.441962 \\
(0.0000)^{* * *}\end{array}$ \\
\hline & $\Delta M_{t-2}$ & $\begin{array}{l}-0.778815 \\
(0.4275) \\
\end{array}$ & $\begin{array}{l}-2.278496 \\
(0.0284)^{* *}\end{array}$ & $\begin{array}{c}2.473596 \\
(0.0001)^{* * *}\end{array}$ \\
\hline & $\begin{array}{c}\text { Conditional Standard } \\
\text { Deviation }\end{array}$ & 0.220834 & 0.241664 & 0.111781 \\
\hline
\end{tabular}

Here $r_{i t}$ is the return of size, value and momentum factors. IP is the industrial production growth,

INF is the realized inflation, and IR is the short term interest rate. TERM is the term spread,

CREDIT is the credit spread and $\triangle \mathrm{M}$ is the growth of money supply; and $I P$ is the Industrial Production index of UK. The values in the parentheses represent the p-values.

*** Implies the significance at $1 \%$ level of significance.

** Implies the significance at 5\% level of significance.

* Implies the significance at $10 \%$ level of significance. 


\section{Table 7: Forecast Evaluation of Portfolios}

This table lists the value of RMSE, MAE and Theil's inequality coefficient is of the out of sample (January'2008 to June'2014) forecasting performance of the markov switching model. The RMSE, MAE and Theil's inequality coefficient is defined as:

$$
R M S E=\sqrt{\frac{1}{N} \sum_{t=1}^{N} e_{t+l, t}^{2}}=\sqrt{\frac{1}{N} \sum_{t=1}^{N}\left(\hat{r}_{t+l}-r_{t+l}\right)^{2}} ; M A E=\frac{1}{N} \sum_{t=1}^{N}\left|e_{t+l, t}\right|=\frac{1}{N} \sum_{t=1}^{N}\left|\left(\hat{r}_{t+l}-r_{t+l}\right)\right| ; \boldsymbol{U}=\frac{\sqrt{\frac{1}{n} \sum_{n=1}^{n}\left(\hat{r}_{t+l}-r_{t+l}\right)^{2}}}{\sqrt{\frac{1}{n} \sum_{n=1}^{n}\left(r_{t+l}\right)^{2}+\sqrt{\frac{1}{n} \sum_{n=1}^{n}\left(\hat{r}_{t+l}\right)^{2}}}}
$$

Here, $\hat{r}_{t+1}$ and $r_{t+1}$ are the observed and predicted value respectively.

\begin{tabular}{|c|c|c|c|c|c|c|c|c|}
\hline & $\begin{array}{c}\text { Small Firms } \\
\text { (Low btm) }\end{array}$ & $\begin{array}{l}\text { Small firms } \\
\text { (High btm) }\end{array}$ & $\begin{array}{l}\text { Big Firms } \\
\text { (Low btm) }\end{array}$ & $\begin{array}{l}\text { Big firms } \\
\text { (High btm) }\end{array}$ & $\begin{array}{l}\text { Small Firms } \\
\text { (Down } \\
\text { momentum) }\end{array}$ & $\begin{array}{l}\text { Small firms } \\
\text { (Up } \\
\text { momentum) }\end{array}$ & $\begin{array}{l}\text { Big Firms } \\
\text { (Down } \\
\text { momentum) }\end{array}$ & $\begin{array}{l}\text { Big firms } \\
\text { (Up } \\
\text { momentum) }\end{array}$ \\
\hline $\begin{array}{l}\text { Root Mean Squared Error } \\
\text { (RMSE) }\end{array}$ & 0.052132 & 0.080217 & 0.064908 & 0.095656 & 0.082478 & 0.052271 & 0.070899 & 0.052364 \\
\hline Mean Absolute Error (MAE) & 0.038683 & 0.055037 & 0.041902 & 0.059657 & 0.055969 & 0.037930 & 0.050508 & 0.040863 \\
\hline $\begin{array}{r}\text { Theil's Inequality Coefficient } \\
\text { Bias Proportion } \\
\text { Variance Proportion } \\
\text { Covariance Proportion }\end{array}$ & $\begin{array}{l}0.650309 \\
0.065172 \\
0.450497 \\
0.484332\end{array}$ & $\begin{array}{l}0.741992 \\
0.011108 \\
0.175088 \\
0.813804\end{array}$ & $\begin{array}{l}0.777735 \\
0.000248 \\
0.019901 \\
0.979852\end{array}$ & $\begin{array}{l}0.762089 \\
0.067968 \\
0.046067 \\
0.885965\end{array}$ & $\begin{array}{l}0.850964 \\
0.001930 \\
0.792952 \\
0.205118\end{array}$ & $\begin{array}{l}0.610728 \\
0.054717 \\
0.676503 \\
0.268780\end{array}$ & $\begin{array}{l}0.885041 \\
0.000728 \\
0.670230 \\
0.329042\end{array}$ & $\begin{array}{l}0.675830 \\
0.000316 \\
0.567688 \\
0.431996\end{array}$ \\
\hline
\end{tabular}


Table 8: Trading Strategy results for eight portfolios (Jan 2008 to Dec 2014)

Trading results are based on the monthly switching between the eight style portfolios (namely: small growth (SL), small value (SH), big growth (BL), big value (BH), small losers (SD), small winners (SU), big losers (BD) and big winners (BU)) and T-bills. A long position in the relevant style portfolio is taken if its return from the recursively predicted by the model is positive, otherwise we invest in one month T-Bill. The buy-and-hold strategy represents the investment in the corresponding style portfolio over the trading period. Annualized mean returns, standard deviations and Sharpe ratios are reported for each style portfolio switching strategy and its buy-and-hold benchmark. The number of switches denotes number of times we switch between the given style portfolio and one month T-bill during the trading period. Break-even transaction costs are maximum costs an investor would pay per switch that equalise the Sharpe ratio of the switching strategy and that of the buy-and-hold. Negative (zero (0.0)) break-even transaction costs imply the Sharpe ratio of the switching strategy was lower (equal to) the Sharpe of the buy-and-hold. Bold denotes the breakeven transaction costs per switch that are large enough to imply the switching strategy is feasible. Panel A reports findings for Small size portfolios and their subgroups while Panel B for large cap portfolios and their subgroups. All results are reported for full out-of-sample period, expansions and recessions separately.

\begin{tabular}{|c|c|c|c|c|c|c|c|c|}
\hline \multirow[t]{2}{*}{ PANEL A } & \multicolumn{2}{|c|}{$\begin{array}{c}\text { Small cap with } \\
\text { low book-to-market (SL) }\end{array}$} & \multicolumn{2}{|c|}{$\begin{array}{c}\text { Small firms with } \\
\text { high book-to-market (SH) }\end{array}$} & \multicolumn{2}{|c|}{$\begin{array}{c}\text { Small Firms with down } \\
\text { momentum (SD) }\end{array}$} & \multicolumn{2}{|c|}{$\begin{array}{l}\text { Small Firms with up momentum } \\
\text { (SU) }\end{array}$} \\
\hline & $\begin{array}{c}\text { Buy and } \\
\text { Hold }\end{array}$ & $\begin{array}{l}\text { Switching } \\
\text { Portfolio }\end{array}$ & $\begin{array}{l}\text { Buy and } \\
\text { Hold }\end{array}$ & $\begin{array}{l}\text { Switching } \\
\text { Portfolio }\end{array}$ & $\begin{array}{c}\text { Buy and } \\
\text { Hold }\end{array}$ & $\begin{array}{l}\text { Switching } \\
\text { Portfolio }\end{array}$ & $\begin{array}{c}\text { Buy and } \\
\text { Hold }\end{array}$ & $\begin{array}{l}\text { Switching } \\
\text { Portfolio }\end{array}$ \\
\hline \multicolumn{9}{|l|}{ Full period } \\
\hline Mean Return & 12.85 & 14.71 & 8.53 & 11.60 & 7.28 & 8.56 & 19.71 & 19.82 \\
\hline Std. Dev. & 17.60 & 17.01 & 24.06 & 22.52 & 29.62 & 25.14 & 18.41 & 18.40 \\
\hline Sharpe Ratio & 0.67 & 0.80 & 0.31 & 0.47 & 0.21 & 0.30 & 1.01 & 1.02 \\
\hline No. of Switches & & 5 & & 11 & & 13 & - & 3 \\
\hline Break Even TC & & 278.56 BPS & & 196.66 BPS & & 108.50 BPS & - & 18.55 BPS \\
\hline \multicolumn{9}{|l|}{ Expansions } \\
\hline Mean Return & 22.51 & 22.51 & 19.07 & 16.15 & 11.99 & 9.32 & 31.76 & 31.76 \\
\hline Std. Dev. & 15.73 & 15.73 & 21.29 & 20.72 & 21.62 & 17.56 & 17.97 & 19.13 \\
\hline Sharpe Ratio & 0.78 & 0.78 & 0.50 & 0.43 & 0.31 & 0.29 & 0.94 & 0.94 \\
\hline No. of Switches & & 0 & & 4 & & 5 & - & 0 \\
\hline Break Even TC & - & 0.00 & - & Negative & & Negative & - & 0.00 \\
\hline \multicolumn{9}{|l|}{ Recessions } \\
\hline Mean Return & 8.02 & 10.81 & 3.27 & 9.33 & 4.93 & 8.18 & 13.69 & 13.85 \\
\hline Std. Dev. & 18.45 & 17.66 & 25.40 & 23.54 & 33.07 & 28.34 & 18.55 & 18354 \\
\hline Sharpe Ration & 0.30 & 0.44 & 0.06 & 0.28 & 0.09 & 0.20 & 0.54 & 0.55 \\
\hline No. of Switches & - & 5 & - & 7 & & 8 & - & 3 \\
\hline Break Even TC & - & 258.12 BPS & - & 383.96 BPS & & 199.12 BPS & - & 22.65 BPS \\
\hline
\end{tabular}




\begin{tabular}{|c|c|c|c|c|c|c|c|c|}
\hline \multirow[t]{2}{*}{ PANEL B } & \multicolumn{2}{|c|}{$\begin{array}{c}\text { Big firms with } \\
\text { low book-to-market (BL) }\end{array}$} & \multicolumn{2}{|c|}{$\begin{array}{c}\text { Big firms with } \\
\text { high book-to-market }(\mathrm{BH})\end{array}$} & \multicolumn{2}{|c|}{$\begin{array}{l}\text { Big Firms with down } \\
\text { momentum (BD) }\end{array}$} & \multicolumn{2}{|c|}{$\begin{array}{l}\text { Big Firms with up } \\
\text { momentum (BU) }\end{array}$} \\
\hline & $\begin{array}{c}\text { Buy and } \\
\text { Hold }\end{array}$ & $\begin{array}{l}\text { Switching } \\
\text { Portfolio }\end{array}$ & $\begin{array}{c}\text { Buy and } \\
\text { Hold }\end{array}$ & $\begin{array}{l}\text { Switching } \\
\text { Portfolio }\end{array}$ & $\begin{array}{c}\text { Buy and } \\
\text { Hold }\end{array}$ & $\begin{array}{l}\text { Switching } \\
\text { Portfolio }\end{array}$ & $\begin{array}{c}\text { Buy and } \\
\text { Hold }\end{array}$ & $\begin{array}{l}\text { Switching } \\
\text { Portfolio }\end{array}$ \\
\hline Full period & & & & & & & & \\
\hline Mean Return & 10.41 & -1.04 & 5.96 & 5.27 & 4.50 & 4.93 & 10.28 & 10.28 \\
\hline Std. Dev. & 12.59 & 7.38 & 17.78 & 16.23 & 23.81 & 23.78 & 19.85 & 19.85 \\
\hline Sharpe Ration & 0.74 & -0.27 & 0.28 & 0.26 & 0.15 & 0.16 & 0.46 & 0.46 \\
\hline No. of Switches & & 6 & & 9 & - & 3 & - & 1 \\
\hline Break Even TC & & Negative & & Negative & - & 68.85 BPS & - & 0.00 \\
\hline Expansions & & & & & & & & \\
\hline Mean Return & 20.22 & 3.10 & 20.52 & 20.66 & 19.13 & 19.13 & 24.16 & 24.16 \\
\hline Std. Dev. & 10.80 & 3.84 & 16.86 & 16.84 & 18.03 & 18.03 & 21.21 & 21.21 \\
\hline Sharpe Ration & 0.98 & 0.39 & 0.67 & 0.67 & 0.59 & 0.59 & 0.63 & 0.63 \\
\hline No. of Switches & - & 2 & & 2 & - & 0 & - & 0 \\
\hline Break Even TC & - & Negative & & Negative & - & 0.00 & - & 0.00 \\
\hline Recessions & & & & & & & & \\
\hline Mean Return & 5.50 & -3.11 & -1.32 & -2.42 & -2.81 & -2.18 & 3.35 & 3.35 \\
\hline Std. Dev. & 13.27 & 8.60 & 18.02 & 15.61 & 26.13 & 26.11 & 19.03 & 19.03 \\
\hline Sharpe Ration & 0.26 & -0.41 & -0.12 & -0.19 & -0.13 & -0.11 & 0.09 & 0.09 \\
\hline No. of Switches & - & 4 & - & 7 & - & 3 & - & 1 \\
\hline Break Even TC & - & Negative & - & Negative & - & 108.28 BPS & - & 0.00 \\
\hline
\end{tabular}

